\title{
Journal of Applied Bacteriology
}

\section{Published for the Society for Applied Bacteriology}

\author{
Editors: M. Sussman Newcastle-upon-Tyne \\ F.A. Skinner Harpenden \\ G.I. Barrow Salisbury
}

The Society for Applied Bacteriology launched the Journal of Applied Bacteriology in 1954 and since that time the journal has grown in size, in prestige and in the subject matter covered. It has established an international reputation with readers and authors; indeed each number of the journal contains papers from worldwide sources. The Society's interest in the systematics and ecology of groups of microorganisms is reflected in the journal, which publishes five types of article:

Review articles: a substantial survey with an adequate historical perspective Observation articles: a succinct discussion of current concepts and developments in applied microbiology

Full-length papers: the development of concepts as well as the recording of facts A note on .... research having narrow, readily defined limits, or contributions to the knowledge but not the development of concepts

Technical notes: details of new methods, techniques or apparatus

\section{Subscription Information}

Journal of Applied Bacteriology is published monthly together with Letters in Applied Microbiology. The subscription also includes the Annual S.A.B. Symposium volume and rates for 1988 are $£ 121.00$ (UK), $\$ 247.50$ (USA \& Canada), $£ 145.00$ (elsewhere) post free.

\section{Order Form}

Please tick the appropriate box and return to Blackwell Scientific Publications Ltd, P.O. Box 88, Oxford, England.

$\square$ I would like to subscribe to Journal of Applied Bacteriology

I wish to pay by cheque/money order (delete as necessary) and enclose the sum of

I wish to pay by Access/Barclaycard/VISA/Mastercard (delere as necessary)

Please debit my credit card no.

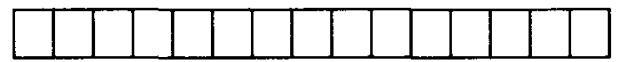

Expiry date.

with the sum of

Signature. Date

Please send me a specimen copy of Journal of Applied Bacteriology

Name

Address

\section{Blackwell Sclentific Publications}

P.O. Box 88, Oxford, England 
Serological tests in leprosy. The sensitivity, specificity and predictive value of ELISA tests based on phenolic glycolipid antigens, and the implications for their use in epidemiological studies

Burgess, P. J., Fine. P. E. M., Ponnighaus, J. M. and Draper, C

Isolation of African swine fever virus from ticks of the Ornithodoros moubate complex (Ixodoidea: Argasidae) collected within the African swine fever enzootic area of Malawi

Haresnape. J. M., Wilkinson, P. J. and Mellor. P. S.

Detection of specific IgM in varicella and herpes zoster by antibody-capture radioimmunoassay

Kangro, H. O., Ward, A., Argent, S., Heath, R. B., Cradock-Watson, J. E. and Ridehalgh. M. K. s. 


\section{Epidemiology and Infection (Formerly the Journal of Hygiene)}

\section{Original reports and reviews on all aspects of infection of man and animals}

\section{CONTENTS}

Special Article. The use of mathematical models in the epidemiological study of infectious diseases and in the design of mass immunization programmes

Nokes, D. J. and Anderson, R. M.

Carriage of Neisseria meningitidis: investigations in a military establishment Pether, J. V. S., Lightfoot, N. F., Scott, R. J. D., Morgan, J., Steele-Perkins, A. P. and Sheard, S. C.

A milk-borne outbreak of serious infection due to Strepotococcus zooepidemicus

(Lancefield Group C)

Edwards, A. T., Roulson, M. and Ironside, M. J.

The use of alkalinity and incubation at $9^{\circ} \mathrm{C}$ for improved recovery of Yersinia spp.

from faeces

Greenwood, M. H. and Hooper, W. L.

Identification of encapsulated and non-encapsulated Yersinia pestis by

immunofluorescence tests using polyclonal and monoclonal antibodies

Phillips, A. P., Morris, B. C., Hall, D., Glenister, M. and Williams, J. E.

Salmonella typhimurium phage type 141 infections in Sheffield during 1984 and 1985 : association with hens' eggs

Chapman, P. A., Rhodes, P. and Rylands, W.

First recognized community outbreak of haemorrhagic colitis due to verotoxinproducing Escherichia coli $\mathrm{O} 157 . \mathrm{H7}$ in the UK

Morgan, G. M., Newman, C., Palmer, S. R., Allen. J. B., Shepherd, W., Rampling, A. M.

Warren, R. E., Gross, R. J., Scotland, S. M. and Smith, H. R.

Cryptosporidium infections in humans with gastroenteritis in Zaria, Nigeria

Kwaga, J. K. P., Umoh, J. U. and Odoba, M. B.

Species identification, antibiotic sensitivity and slime production of coagulase-

negative staphylococci isolated from clinical specimens

Deighton, M. A., Franklin, J. C., Spicer, W. J. and Balkau, B.

Poultry-borne salmonellosis in Scotland

Reilly, W. J., Forbes, G. I., Sharp, J. C. M., Oboegbulem, S. I., Collier, P. W. and

Paterson, G. M.

Prospective study of diarrhoeal disease in a cohort of rural Mexican children:

incidence and isolated pathogens during the first two years of life

Cravioto, A., Reyes, R. E., Ortega, R., Fernández, G., Hernández, R. and Lopez, D.

Washing with contaminated bar soap is unlikely to transfer bacteria

Heinze, J. E. and Yackovich, F.

Serratia marcescens infection associated with early abortion in cows and buffaloes Das, A. M., Paranjape, V. L. and Pitt, T. L.

Antigenic analysis of Haemophilus ducreyi by Western blotting

Abeck, D., Johnson, A. P. and Taylor-Robinson, D.

\section{Cambridge University Press}

The Pitt Building, Trumpington Street, Cambridge CB2 1RP

32 East 57th Street, New York, NY 10022, USA

10 Stamford Road, Oakleigh, Melbourne, 3166, Australia

(C) Cambridge University Press 1988

Printed in Great Britain by the University Press, Cambridge 